\title{
HEAVY METALS IN THE BURROWING BIVALVE SCROBICULARIA PLANA FROM THE TAMAR ESTUARY IN RELATION TO ENVIRONMENTAL LEVELS
}

\author{
G. W. BRYAN* AND H. UYSALt \\ * The Laboratory, Marine Biological Association, Citadel Hill, Plymouth \\ † Department of General Zoology, Ege University, Bornova-Izmir, Turkey
}

(Figs. 1-8)

\begin{abstract}
Concentrations of ten metals ( $\mathrm{Ag}, \mathrm{Cd}, \mathrm{Co}, \mathrm{Cr}, \mathrm{Cu}, \mathrm{Fe}, \mathrm{Mn}, \mathrm{Ni}, \mathrm{Pb}, \mathrm{Zn}$ ) have been measured in the whole soft parts and digestive gland of the burrowing bivalve Scrobicularia plana (da Costa) over its range of distribution in the Tamar estuary. Four metals $(\mathrm{Cu}, \mathrm{Fe}, \mathrm{Mn}, \mathrm{Zn})$ have been analysed in the individual tissues including the shell. As far as possible, concentrations in the animals have been related to those in the environment. Seasonal variation, level on the shore and size of animal have also been considered.

Partitioning of metals between the digestive gland and remaining soft tissues suggests that uptake of $\mathrm{Cd}, \mathrm{Co}, \mathrm{Cr}, \mathrm{Ni}, \mathrm{Pb}$ and $\mathrm{Zn}$ occurs mainly through ingestion of sediments. Generally, more than $75 \%$ of these metals was found in the digestive gland. This organ contributed less to the total amount of $\mathrm{Cu}$ and $\mathrm{Ag}(30-40 \%), \mathrm{Mn}(51-80 \%)$ and $\mathrm{Fe}(3-20$ $\%)$. Lower values of $\mathrm{Mn}$ and $\mathrm{Fe}$ were found upstream where the availability of 'soluble' metals to the animals was higher. Concentrations of $\mathrm{Cd}, \mathrm{Co}, \mathrm{Cr}, \mathrm{Ni}, \mathrm{Pb}$ and $\mathrm{Zn}$ in the whole soft parts increased markedly with size, whereas $\mathrm{Fe}$ remained relatively constant and levels of $\mathrm{Ag}, \mathrm{Cu}$ and $\mathrm{Mn}$ decreased.

In the shell, most of the Mn was incorporated in the matrix, presumably via the mantle, whereas appreciable amounts of $\mathrm{Cu}, \mathrm{Fe}$ and $\mathrm{Zn}$ were probably incorporated directly from solution by adsorption.

Scrobicularia appears to have potential as an indicator of the availability of metals in estuaries and results for $\mathrm{Cu}, \mathrm{Fe}, \mathrm{Mn}$ and $\mathrm{Zn}$ suggest that there were no important changes in the Tamar estuary between 1969 and 1974.
\end{abstract}

\section{INTRODUCTION}

The bivalve mollusc Scrobicularia plana (da Costa) is very common in the estuaries of South-West England and lives in permanent burrows in intertidal sediments ranging from soft mud to fairly hard sand and sometimes gravel. Although it obtains some of its food by filtering the overlying water, Scrobicularia is mainly a deposit feeder (Hughes, 1969). In addition to its widespread distribution, Scrobicularia has several features which make it attractive as a possible indicator organism for metallic contamination. It is more tolerant of low salinities than most common estuarine bivalves, usually penetrating farther upstream than Macoma balthica, Mytilus edulis and Cerastoderma edule (Percival, 1929; Spooner \& Moore, 1940; Bryan \& Hummerstone, 1977). Also, it lives for over ten years, usually attaining a length of $4-5 \mathrm{~cm}$, and its rate of growth can be estimated from rings on the shell (Green, 1957; Hughes, 1970).

The estuary of the River Tamar drains a metalliferous area in South-West England where, until about the turn of the century, metals including copper, tin, lead, silver and 
arsenic were mined (Fig. 1). In an earlier series of papers, relationships were described between concentrations of metals in the Tamar sediments and in the burrowing polychaete Nereis diversicolor (Bryan \& Hummerstone, 1971, 1973a,b) and between concentrations in the water and the brown seaweed Fucus vesiculosus (Bryan \& Hummerstone, 1973c).

This paper describes our work with Scrobicularia plana in the Tamar and discusses relationships between concentrations of metals in the animal and those in its environment.

\section{MATERIALS AND METHODS}

During 1969, 1970 and 1974, Scrobicularia was collected from the middle of its vertical range of distribution at as many as nine stations on the intertidal mudflats (Fig. 1). Animals of a similar size (shell length $4 \mathrm{~cm}$ ) were collected from all stations, plus a range of sizes from the 11 and 12.5 $\mathrm{km}$ stations. On several occasions, samples of Fucus vesiculosus and sediment cores were also collected. The sampling of Fucus has been described by Bryan \& Hummerstone (1973c).

Prior to analysis Scrobicularia were kept for 1 week in diluted sea water to allow the removal of ingested particles. Samples of whole soft parts or of individual tissues were pooled from between 5 and 10 animals. Dried tissues were digested with concentrated nitric acid at about $100{ }^{\circ} \mathrm{C}$ in flasks sealed with glass bubbles. After digestion the sample was evaporated. The residue was dissolved in $6 \mathrm{~N}$ hydrochloric acid and diluted to $1.2 \mathrm{~N}$. Analyses were carried out by atomic absorption and background correction was employed for silver, cadmium, cobalt, nickel and lead.

The shells of freshly collected Scrobicularia were cleaned with a jet of tap water and, following the cleansing period and removal of the soft parts, soaked in distilled water overnight and air dried (washed shells). Additional material was removed from the outer surface of some shells with a nylon brush (scrubbed shells). Shells were dissolved in hydrochloric acid and, following evaporation, were reconstituted in dilute hydrochloric acid. All shell analyses were corrected for non-atomic absorption.

In this paper, analyses of sediments mainly refer to air-dried surface samples which were digested in the same way as tissue samples using $20 \mathrm{ml}$ of nitric acid for $0.4 \mathrm{~g}$ of material. Some samples were studied in more detail. Particle size measurements were made using an Andreasen's pipette and British Standard Method 1377 (1961). Total concentrations were measured in samples which had been ashed at $500^{\circ} \mathrm{C}$ and dissolved in hydrofluoric acid (Langmyr \& Paus, 1968) and extractability of metals from the sediment was assessed using the acetic acid/hydroxylamine hydrochloride mixture described by Chester \& Hughes (1967). Analyses were carried out in the same way as those for the tissues, with the exception that correction was necessary for the interference of iron with the analysis of chromium using the air-acetylene flame.

The salinity of interstitial water from the sediment was found by analysing sodium in small samples extracted from sections of cores by suction.

\section{RESULTS}

\section{Distribution of Scrobicularia in relation to sediment salinity}

Since salinity may be an important factor governing the availability of metals to Scrobicularia, measurements were made of the salinity of the interstitial water at different depths in the sediment at different times of year. In the top $5 \mathrm{~cm}$ the interstitial salinity may reflect average conditions in the overlying water during the previous few days, whereas at $15-20 \mathrm{~cm}$ the values seem more likely to reflect seasonal conditions. The results obtained following periods of high and low rainfall show that, beyond the point where the estuary narrows $13 \mathrm{~km}$ from the mouth, the salinity of interstitial water varies over a very wide range (Fig. 2). Living Scrobicularia have been collected more than $18 \mathrm{~km}$ 


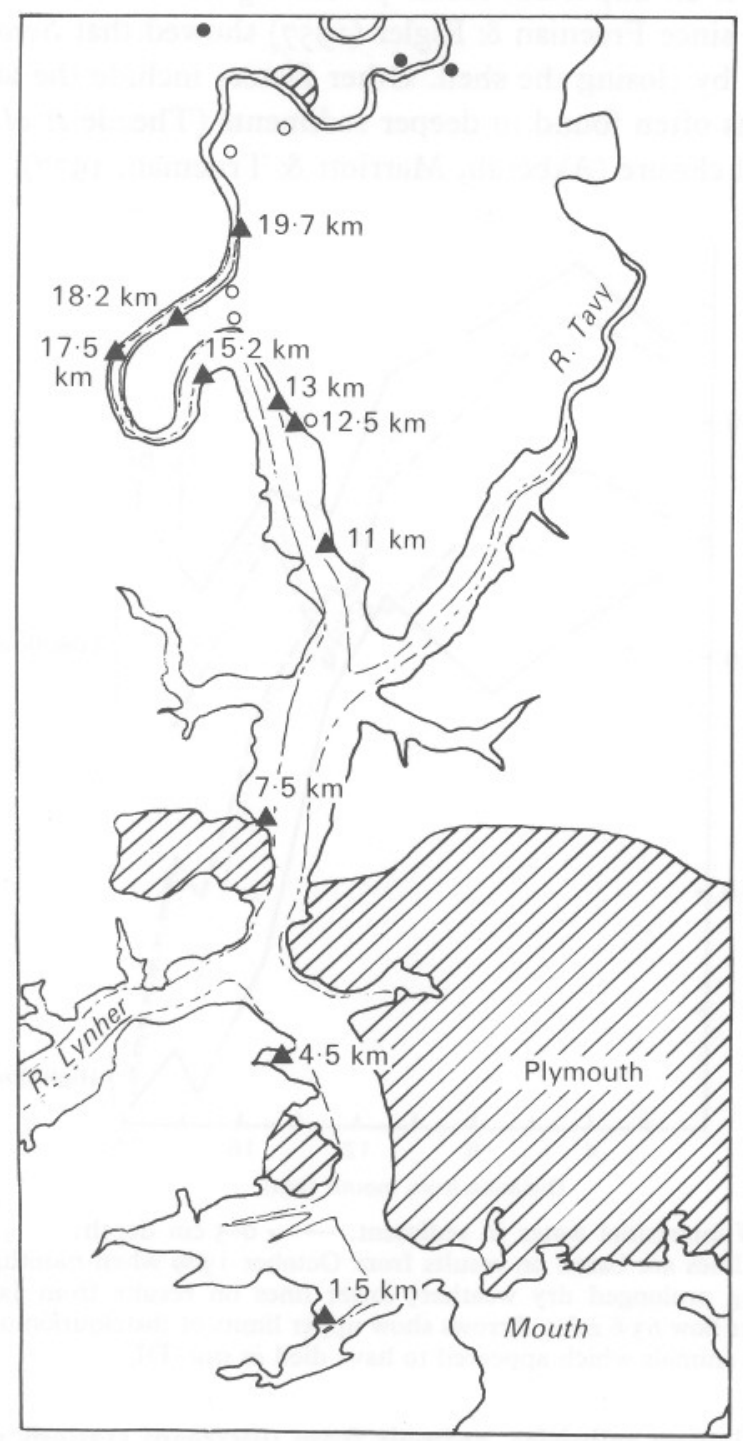

Fig. 1. Tamar estuary showing sampling stations $(\boldsymbol{\Lambda})$ with distance from mouth in $\mathrm{km}$. Also shown are sites of some old lead mines $(O)$ and copper mines $(\bullet)$. Based on the $1: 25000$ Ordnance Survey Map with the sanction of the controller of H.M. Stationery Office, Crown copyright reserved.

from the mouth and a few shells of about $2 \mathrm{~cm}$ length which appeared to have died in situ were collected at $19.7 \mathrm{~km}$. In the laboratory, animals exposed continuously to a salinity of $3.5 \%$ at $13{ }^{\circ} \mathrm{C}$ were moribund after a week. Fig. 2 shows that during a period of high flow the interstitial salinity in the top $5 \mathrm{~cm}$ of sediment at $18 \mathrm{~km}$ was below $3.5 \%$, which suggests that values for the overlying water were equally low. Scrobicularia lives at a depth of about $25 \mathrm{~cm}$ in the sediment at $18 \mathrm{~km}$ and, even under conditions of high river flow, the interstitial salinity at this depth probably exceeded 
$10 \%$ (Fig. 2). This is an important factor protecting the animal from low salinities in the overlying water, since Freeman \& Rigler (1957) showed that Scrobicularia responds to lowered salinities by closing the shell. Other factors include the ability to withstand the anoxic conditions often found in deeper sediments (Theede et al. 1969) and anoxia associated with shell closure (Akberali, Marriott \& Trueman, 1977).

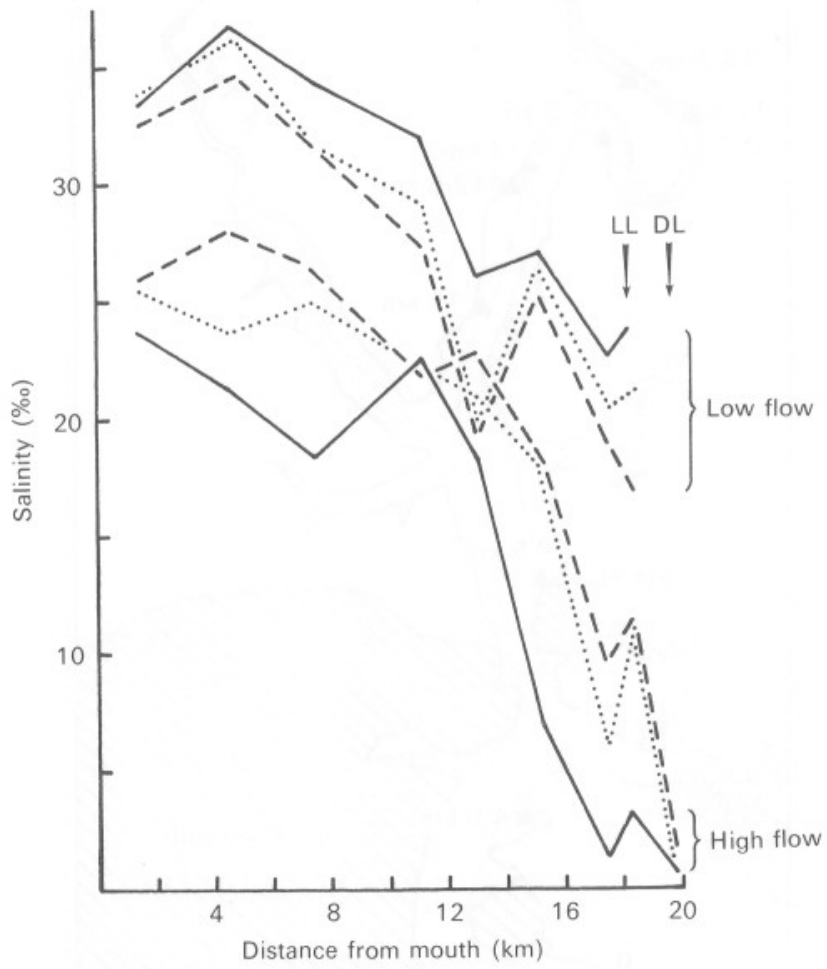

Fig. 2. Salinity of interstitial water in sediment.,$- 0-5 \mathrm{~cm}$ depth; $\cdots, 10-15 \mathrm{~cm} ;----$, $15-20 \mathrm{~cm}$. Upper lines are based on results from October 1969 when monthly mean river flow $3.56 \mathrm{~m}^{3} / \mathrm{s}$ following prolonged dry weather; lower lines on results from January 1970 when monthly mean river flow $63.6 \mathrm{~m}^{3} / \mathrm{s}$. Arrows show upper limits of distribution of live Scrobicularia plana (LL) and of animals which appeared to have died in situ (DL).

By avoiding the lowest salinities, animals from upstream stations are almost certainly exposed to the overlying water for a shorter period than those downstream and are not necessarily exposed to the same average conditions as, for instance, seaweed at the same site. There is also the possibility that chemical changes in the water of the mantle cavity and the tissues resulting from anoxia (Akberali et al. 1977) might change the availability of metals from sediment particles retained in the animal. The low interstitial salinities observed even in deep sediment at $19.7 \mathrm{~km}$ when the river flow was high (Fig. 2) are probably the reason why the species has been unable to establish itself at this site, other than for perhaps a few years. 


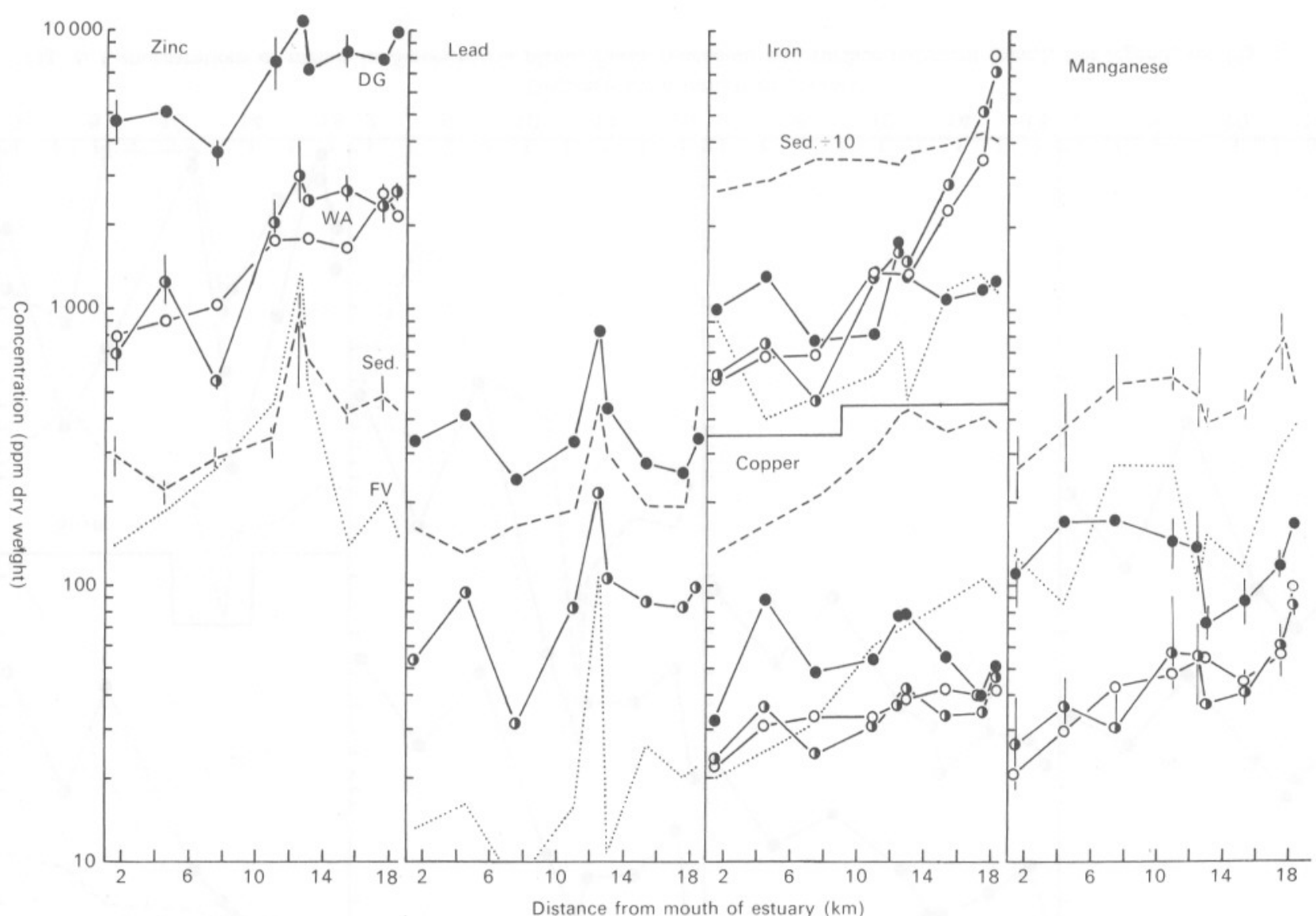

Fig. 3. Concentrations of metals in Scrobicularia plana, Fucus vesiculosus and surface sediment. ๑, Digestive gland (DG)-1974; (), whole soft parts (WA)-1974; O, whole soft parts (WA)-1969-70; … Fucus vesiculosus (FV)-older thallus, Nov. 1974; -----, surface sediment (sed.)-1974. Vertical lines show examples of range of 1974 values. Results for 1969-70 are mean values from five seasonal samples of about five pooled animals each. Results for 1974 are mean values for July and November surveys each involving pooled samples of about five digestive glands, two pooled samples of five whole animals, a surface sediment sample and a seaweed sample (November only). 


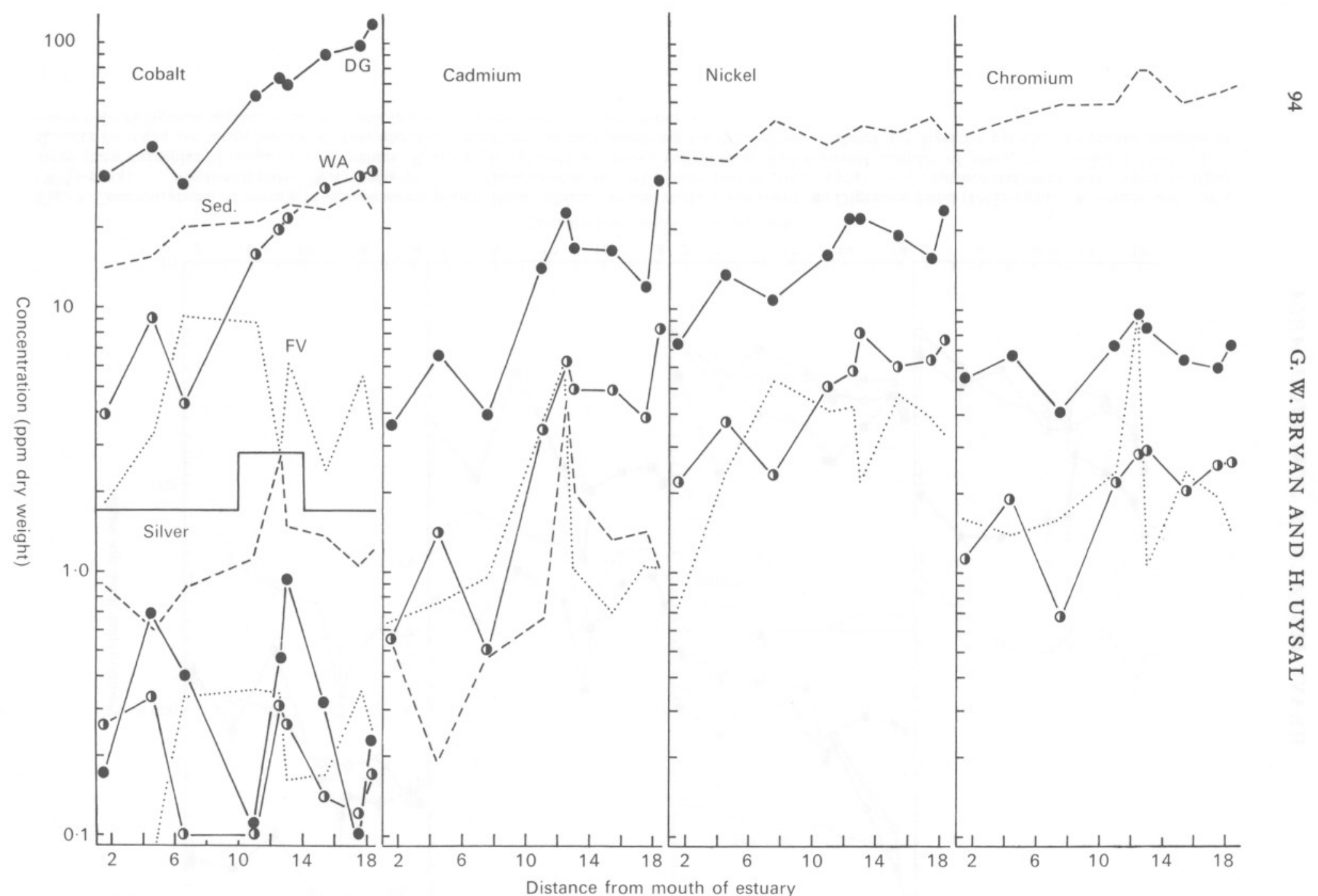

Fig. 4. Concentrations of metals in Scrobicularia plana, Fucus vesiculosus and surface sediment (cont.). For legend, see Fig. 3. 


\section{Concentrations of metals in Scrobicularia}

Metals in whole soft parts

Mean concentrations. During 1969-70 concentrations of zinc, copper, manganese and iron were measured on five occasions. In July and November 1974 this range of metals was extended to include silver, cadmium, cobalt, chromium, nickel and lead. The mean values for 1969-70 and 1974 are both shown in Figs. 3 and 4 and are compared with concentrations in the digestive gland, surface sediment and Fucus vesiculosus. Little change in the metal concentrations of the whole soft parts was evident between 1969-70 and 1974 .

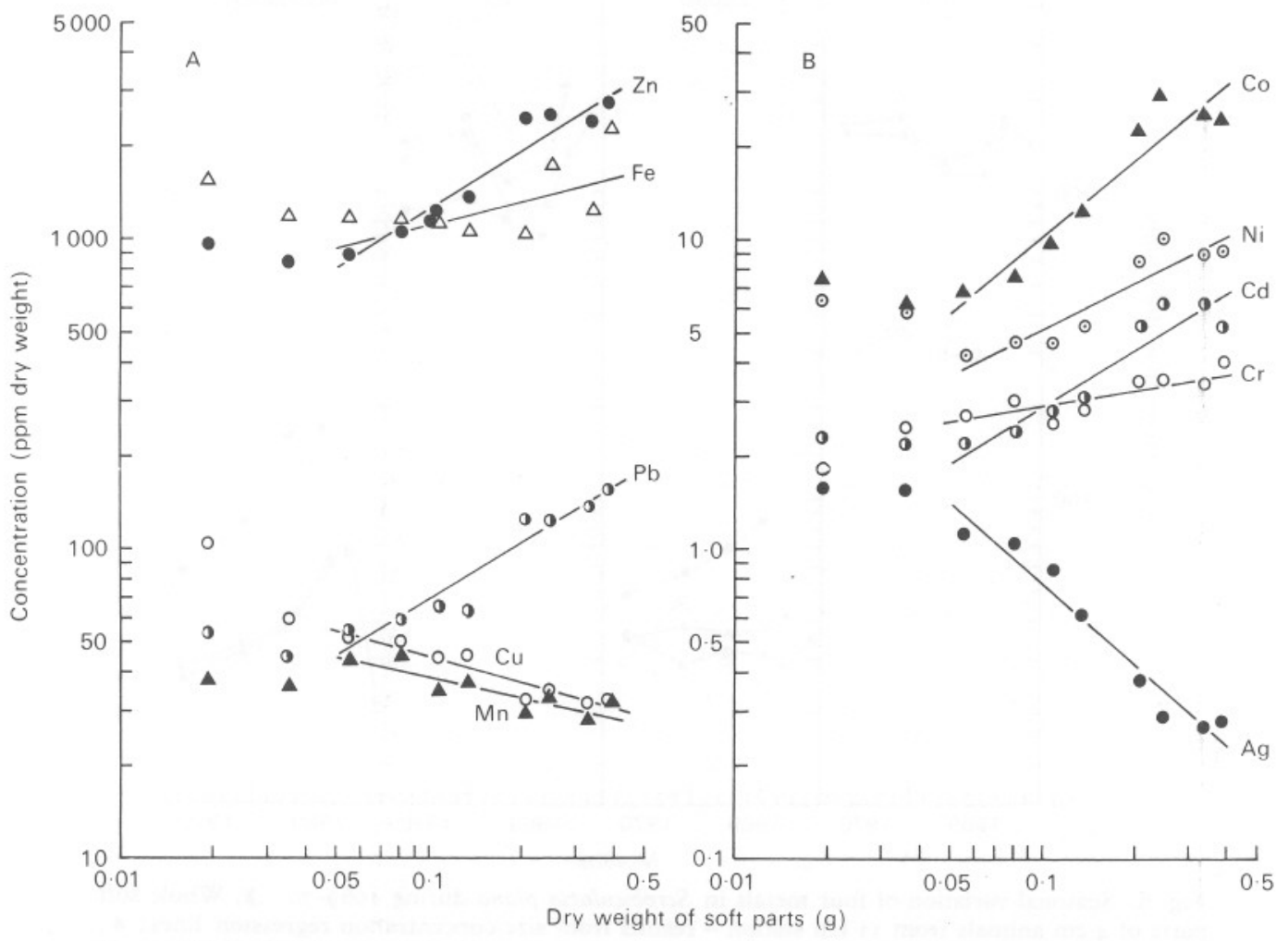

Fig. 5. ( $A \& B$ ). Relationships between concentrations of ten metals and the dry weight of the whole soft parts of Scrobicularia plana at $12.5 \mathrm{~km}$ station in Feb. 1975. For animals over 0.05 g dry weight, slopes $(m)$ for the linear regression equation, $\log _{10}$ concentration $=m \log _{10}$ weight + $\log _{10}$ intercept, are: $\mathrm{Ag},-0.857 ; \mathrm{Cd}, 0.606 ; \mathrm{Co}, 0.817 ; \mathrm{Cr}, 0.188 ; \mathrm{Cu},-0.280 ; \mathrm{Fe}, 0.241 ; \mathrm{Mn}$, $-0.215 ; \mathrm{Ni}, 0.505 ; \mathrm{Pb}, 0.603 ; \mathrm{Zn}, 0.639$. Each point represents about five pooled animals.

Influence of size. Boyden (1974) showed that often in molluscs there is a linear relationship when metal concentration is plotted against body weight (without shell) on logarithmic scales. Fig. 5 shows that in Scrobicularia metal concentration is linearly related to body weight in all except the smallest animals. With the exception of iron, all the slopes differ significantly from zero $(P<0.05)$. Concentrations of zinc, lead, cobalt, 
nickel, cadmium and chromium increase with increasing weight but concentrations of copper, manganese and silver fall.

Seasonal variations. Size/concentration regressions were used to compare metal concentrations in animals of exactly $4 \mathrm{~cm}$ length collected from the $11 \mathrm{~km}$ station at different times during 1969-70. Since the dry weight of the soft parts and the lengths of the animals were known, it was easy to deduce the concentrations at $4 \mathrm{~cm}$ length from results plotted in terms of dry weight as in Fig. 5. The results in Fig. 6 show that there

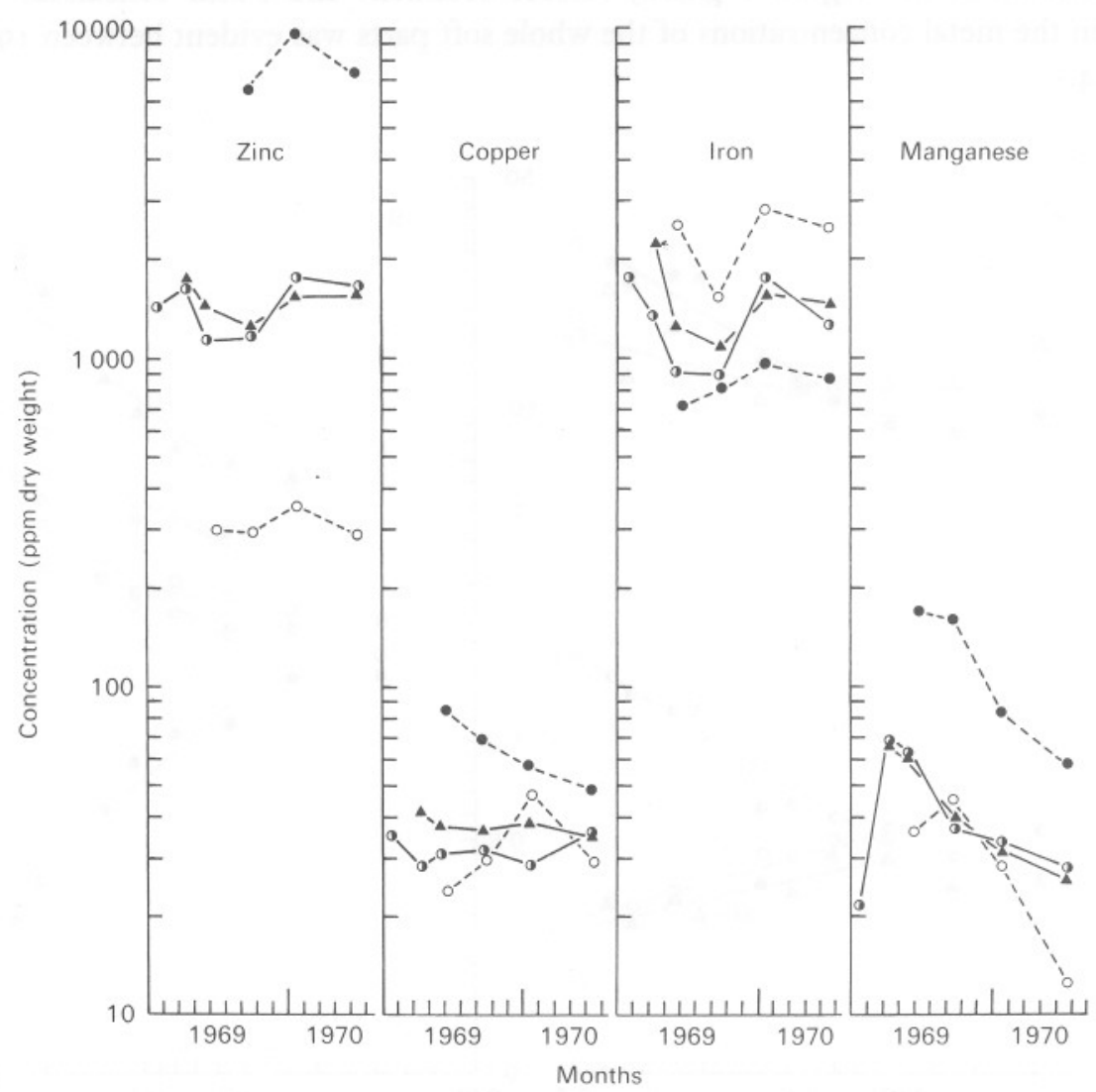

Fig. 6. Seasonal variation of four metals in Scrobicularia plana during 1969-70. Whole soft parts of $4 \mathrm{~cm}$ animals from $11 \mathrm{~km}$ station - results from size/concentration regression lines; $\boldsymbol{\Delta}$, mean values for whole soft parts of animals from all 7 stations between 1.5 and $17.5 \mathrm{~km} ; \boldsymbol{\bullet}$, digestive gland; $O$, mantle/siphons from $11 \mathrm{~km}$ station - samples pooled from 10 animals.

was little seasonal change in the concentration of copper in the whole soft parts, whereas the concentration of manganese reached a very definite peak in the summer. Levels of iron and zinc were highest in winter and spring, and lowest in the late summer. Values for the estuary as a whole, averaged from 7 stations, gave a similar pattern to the results from the $11 \mathrm{~km}$ station (Fig. 6).

Influence of shore level. At the $11 \mathrm{~km}$ station, Scrobicularia were analysed from the middle, upper and lower limits of distribution of the species in the intertidal zone. For all ten metals similar values were found for the middle and lower samples but, with the excep- 
tion of zinc and manganese, concentrations were $1 \cdot 5^{-2}$ times higher in the upper sample. This is surprising, since concentrations in the surface sediment and in Fucus vesiculosus collected at the same time decreased with increasing height on the shore.

\section{Metals in individual tissues}

The digestive gland accounts for about $25 \%$ of the dry weight of the soft parts but usually accounts for a much higher percentage of the total metal content. For $4 \mathrm{~cm}$ animals from the $11 \mathrm{~km}$ station in July 1974 these percentages were: silver 15.5 , cadmium

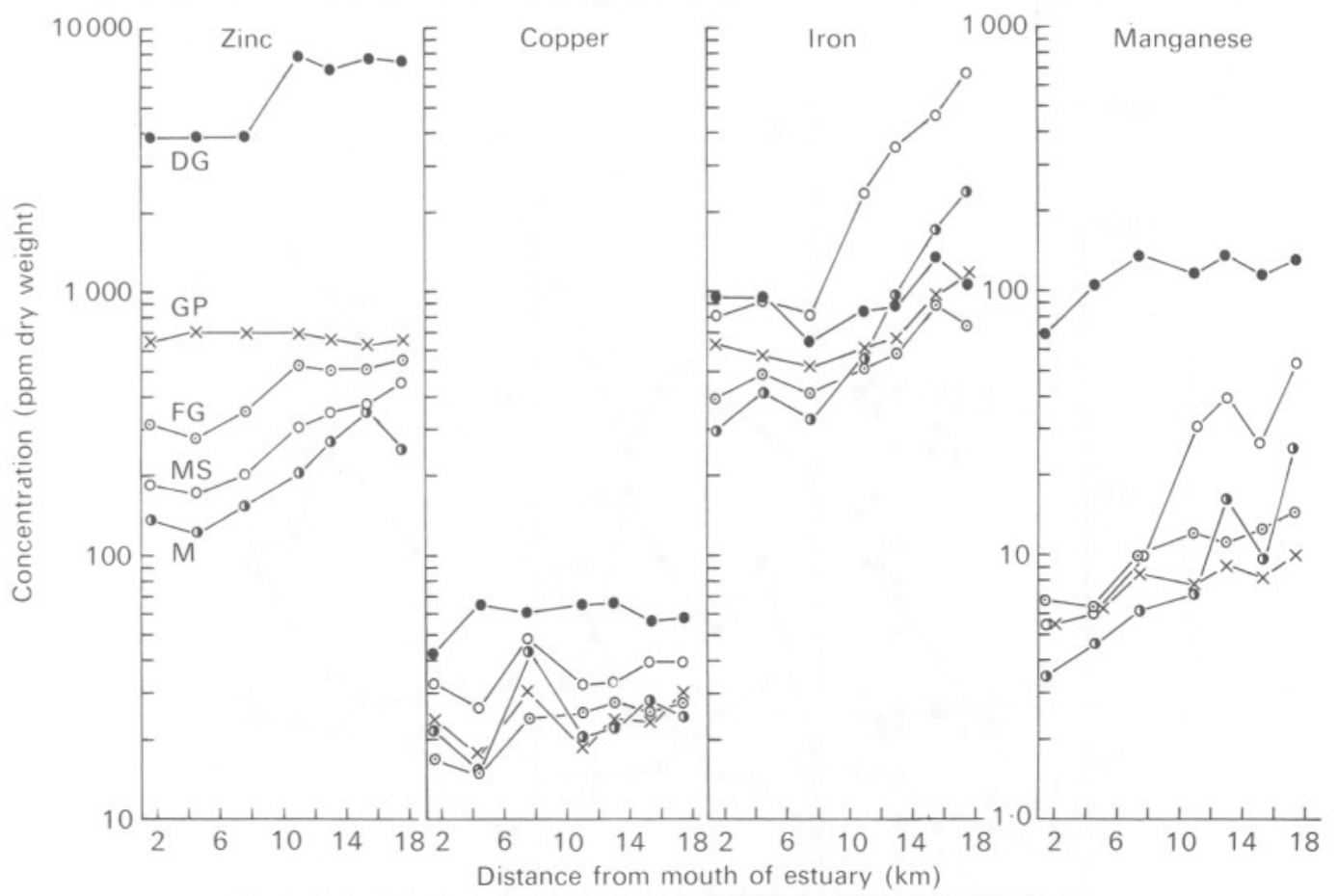

Fig. 7. Concentrations of four metals in tissues during 1969-70. Each point is a mean of four seasons and represents 40 animals. Digestive gland; $\times$, gills and labial palps; $O$, mantle and siphons; $\odot$, foot and gonad; $\odot$, adductor muscles. Contribution of tissues to dry weight of soft parts (including body fluid) was about $25 \%$ each for digestive gland, mantle/siphons and foot/ gonad, about $7 \%$ for adductor muscles and $6 \%$ for gills/labial palps.

95, cobalt 94, chromium 80, copper 38 , iron 10.3 , manganese 73 , nickel 83 , lead 85 and zinc 87 . As a result, the patterns of change with distance and time within the estuary for most metals are similar in the digestive gland and whole soft parts (Figs. 3, 4, 6 and 7). Iron is the most obvious exception to this rule.

During the 1969-70 surveys, four other tissues were analysed for copper, iron, manganese and zinc and the results are shown in Fig. 7. Generally speaking, the pattern shown by the digestive gland is mirrored by the foot/gonad and that shown by the mantle/siphons is mirrored by the adductor muscles. Perhaps due to cleaning the animals for a week prior to analysis, the gills/labial palps show less evidence of differences within 
the estuary than other tissues. Kidney tissue was not usually analysed because it is a small organ and did not contain especially high concentrations of metals.

Seasonal changes were observed in most tissues and Fig. 6 compares results for the digestive gland and mantle/siphons with those for the whole soft parts. Changes in the concentration of zinc are not very obvious in most tissues and changes in the whole soft parts depend largely on those in the concentration and bulk of the digestive gland. For iron, the most obvious changes occur in the mantle/siphons which account for about $25 \%$ of the dry weight of the soft parts. There is some evidence in Fig. 6 for the seasonal redistribution of copper between the tissues, although there is little change in the animal as a whole. Changes in the concentration of manganese were observed in all tissues.

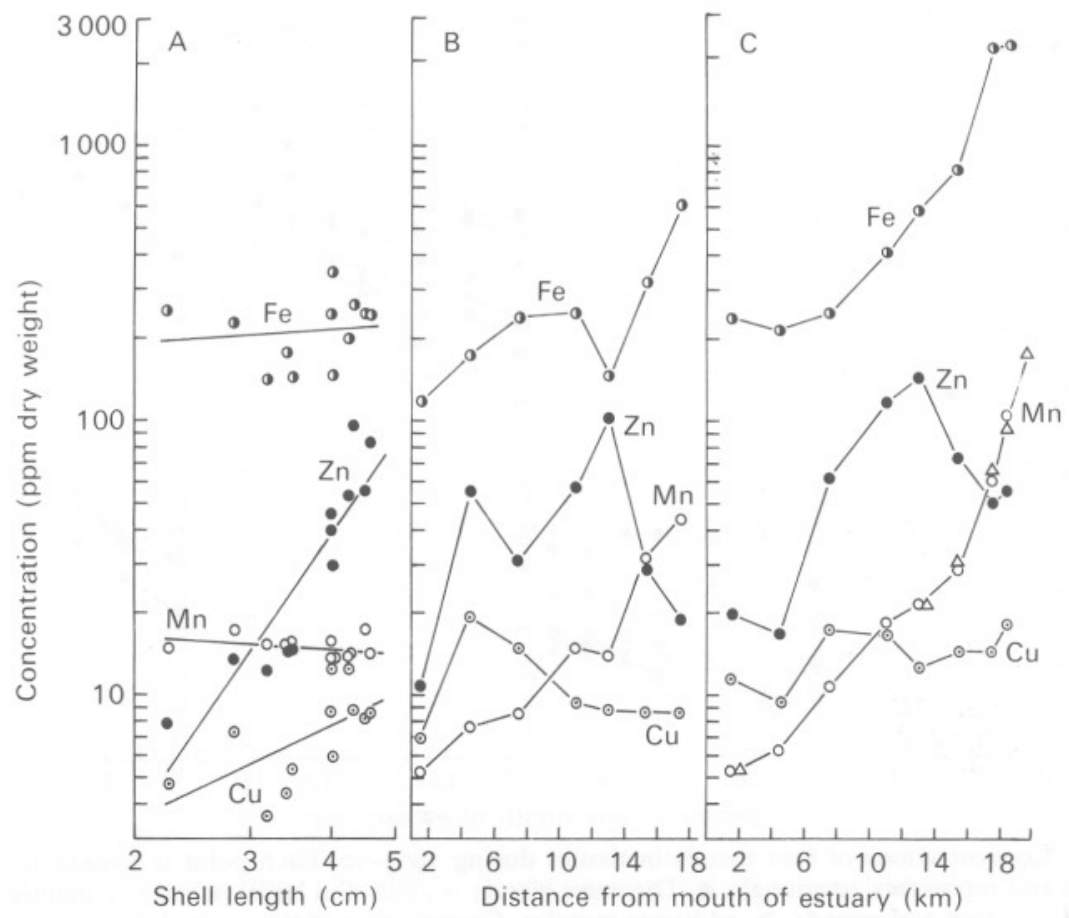

Fig. 8 (A) Effect of shell length on metal concentrations in scrubbed shells from $11 \mathrm{~km}$ station in October 1970. Slopes $(m)$ for linear regression equation, $\log _{10}$ concentration $=m \log _{10}$ shell length $+\log _{10}$ intercept, are: $\mathrm{Zn}, 3.425 ; \mathrm{Cu}, 1.102 ; \mathrm{Mn},-0.115 ; \mathrm{Fe}, 0.166$; of which the first two are significantly different $(P<0.05)$ from a slope of zero. Points are for single shells over $4 \mathrm{~cm}$ length, or, for smaller shells, pooled samples of 2-3. (B) Concentrations of metals in scrubbed shells from October 1970. Each point is a mean from five shells. (C) Concentrations of metals in washed shells collected at four seasons during 1969-70. Each point represents about 40 shells. $\triangle$, Manganese concentrations in buried shells of animals which appeared to have died in situ.

\section{Shell}

Although washing the animal in a jet of tapwater removed adhering sediment from the shell, a more firmly attached coating containing metals remained. This could be removed by scrubbing the shell with a brush. Comparisons between washed and scrubbed 
valves from $4 \mathrm{~cm}$ animals at the $11 \mathrm{~km}$ station showed that scrubbing removed an additional $20 \%$ of the manganese, $50 \%$ of copper, $60 \%$ of iron and $70 \%$ of zinc.

Changes in concentrations with distance along the estuary are shown for both washed and scrubbed shells in Fig. 8 and also shown is the influence of size on the analyses of scrubbed shells from the $11 \mathrm{~km}$ station. Concentrations of manganese and iron are relatively independent of size and increase markedly upstream. Copper levels tend to increase with size but do not change markedly along the estuary and zinc levels increase markedly with size and show a peak in the middle reaches of the estuary. Mean values for scrubbed shells of $4 \mathrm{~cm}$ or more in length from the $11 \mathrm{~km}$ station are shown in Table 1. The variability is typical of results for the estuary as a whole, with manganese showing least variation and zinc the most. Also shown in Table 1 are results from three different sections of scrubbed shells. The shells were broken along growth lines to give approximately equal samples. With the exception of iron, concentrations decrease in a radial direction, from the older umbo region to the edge of the shell.

Table 1. Concentrations of metals in scrubbed, air-dried shells from the $11 \mathrm{~km}$ station

\begin{tabular}{|c|c|c|c|c|c|}
\hline \multicolumn{6}{|c|}{$\begin{array}{l}\text { Mean and standard deviation for } 7 \text { shells of } 4-4.6 \mathrm{~cm} \text { length } \\
\text { in } 1970 \text { (ppm dry weight) }\end{array}$} \\
\hline $\mathrm{Cu}$ & $\mathrm{Fe}$ & Mn & \multicolumn{2}{|c|}{$\mathrm{Zn}$} & \\
\hline \multirow[t]{3}{*}{$\begin{array}{c}9.2 \\
\pm 2 \cdot 3 \\
( \pm 25 \%)\end{array}$} & $\begin{array}{c}240 \\
\pm 60 \\
( \pm 25 \%)\end{array}$ & $\begin{array}{c}14.7 \\
\pm 1.5 \\
( \pm 10.2 \%)\end{array}$ & & $\begin{array}{l}9 \\
\% \\
\%\end{array}$ & \\
\hline & \multicolumn{5}{|c|}{$\begin{array}{l}\text { Mean concentrations from four shells divided into three } \\
\text { fractions in } 1974\end{array}$} \\
\hline & $\begin{array}{l}\% \text { of } \\
\text { total weight }\end{array}$ & $\mathrm{Cu}$ & $\mathrm{Fe}$ & Mn & $\mathrm{Zn}$ \\
\hline Umbo region & $31 \cdot 2$ & 29 & 153 & $19 \cdot 3$ & 91 \\
\hline Intermediate region & 28.9 & $5 \cdot 5$ & 130 & $18 \cdot 3$ & 74 \\
\hline Edge region & 39.9 & $5 \cdot 0$ & 150 & $13 \cdot 0$ & 29 \\
\hline Whole shell & 100 & $12 \cdot 6$ & 145 & 16.5 & 61 \\
\hline
\end{tabular}

\section{Metals in the sediments}

The majority of results refer to sediments digested in nitric acid. Compared with total solution in hydrofluoric acid this method extracted virtually all the copper, lead and zinc and over 90\% of the manganese and iron (Bryan \& Hummerstone, 1971). Changes in surface sediment concentrations along the estuary in 1974 are shown in Figs. 3 and 4 for comparison with Scrobicularia. For some metals, including zinc, lead, manganese and cadmium, the patterns of change shown by the whole soft parts and sediments are not dissimilar. For others, such as iron and cobalt, there are very clear differences.

To obtain more information, a series of surface samples was taken from each of four stations and, following particle size measurements, two samples were selected from each station which seemed to afford the closest comparison with the others. The dry samples were extracted with the acetic acid/hydroxylamine hydrochloride mixture which should dissolve absorbed metals and those associated with iron and manganese oxides 
and carbonate minerals, but not those incorporated into the structural lattice of minerals. The results for total, extractable and non-extractable metals are summarized in Table 2. With the exception of lead, the total and extractable concentrations fall downstream. As a percentage of the total, extractable lead tends to increase downstream, perhaps reflecting additional input in the lower reaches. The percentage of extractable copper and zinc remains fairly constant along the estuary, and that of iron falls slightly. It is thought that the fall in the percentage of extractable manganese downstream results from its remobilisation from the sediments (Bryan \& Hummerstone, 1973b,c).

Table 2. Total and extractable and non-extractable concentrations of metals in surface sediments

Metals were extracted from air-dried sediment with the acetic acid-hydroxylamine hydrochloride mixture of Chester \& Hughes (1967). Results are mean values from two different samples collected in September 1972. Non-extractable concentrations were determined by difference.

$\begin{array}{lcccr}\text { Distance from mouth (km) } \ldots & 29 & 17 \cdot 5 & 11 & 2 \cdot 5 \\ \text { Salinity of interstitial water (\%) } & 0.7 & 32 \cdot 7 & 32 \cdot 7 & 33.5 \\ \text { Weight lost at } 500{ }^{\circ} \mathrm{C}(\%) & 10.3 & 9 \cdot 8 & 9 \cdot 0 & 8 \cdot 1 \\ \text { Fraction }<16 \mu \mathrm{m}(\%) & 64 & 50 & 54 & 57\end{array}$

Concentrations (ppm air-dried sediment)

\begin{tabular}{|c|c|c|c|c|c|}
\hline Copper & $\begin{array}{l}\text { Total HF soluble } \\
\text { Extractable } \\
\text { Non-extractable }\end{array}$ & $\begin{array}{l}433 \\
136(31.5 \%) \\
297\end{array}$ & $\begin{array}{l}343 \\
117(34 \cdot 2 \%) \\
226\end{array}$ & $\begin{array}{l}348 \\
115(33.0 \%) \\
233\end{array}$ & $\begin{array}{r}199 \\
71(35 \cdot 7 \%) \\
128\end{array}$ \\
\hline Iron & $\begin{array}{l}\text { Total HF soluble } \\
\text { Extractable } \\
\text { Non-extractable }\end{array}$ & $\begin{array}{l}43890 \\
9340(21 \cdot 3 \%) \\
34550\end{array}$ & $\begin{array}{l}38100 \\
8380(22.0 \%) \\
29720\end{array}$ & $\begin{array}{l}39128 \\
8098(20.7 \%) \\
31030\end{array}$ & $\begin{array}{l}33060 \\
5520(16.7 \%) \\
27540\end{array}$ \\
\hline Manganese & $\begin{array}{l}\text { Total HF soluble } \\
\text { Extractable } \\
\text { Non-extractable }\end{array}$ & $\begin{array}{l}690 \\
452(65 \cdot 6 \%) \\
238\end{array}$ & $\begin{array}{l}520 \\
308(59 \cdot 3 \%) \\
212\end{array}$ & $\begin{array}{l}425 \\
216(50.8 \%) \\
209\end{array}$ & $\begin{array}{l}289 \\
84 \\
205\end{array}(29 \cdot 1 \%)$ \\
\hline Lead & $\begin{array}{l}\text { Total HF soluble } \\
\text { Extractable } \\
\text { Non-extractable }\end{array}$ & $\begin{array}{l}266 \\
156(58.8 \%) \\
110\end{array}$ & $\begin{array}{l}212 \\
145(68 \cdot 4 \%) \\
67\end{array}$ & $\begin{array}{l}254 \\
164(64.6 \%) \\
90\end{array}$ & $\begin{array}{l}230 \\
169(73.5 \%) \\
61\end{array}$ \\
\hline Zinc & $\begin{array}{l}\text { Total HF soluble } \\
\text { Extractable } \\
\text { Non-extractable }\end{array}$ & $\begin{array}{l}461 \\
332(72 \cdot 0 \%) \\
129\end{array}$ & $\begin{array}{l}396 \\
295(74 \cdot 6 \%) \\
101\end{array}$ & $\begin{array}{l}393 \\
269(68 \cdot 4 \%) \\
124\end{array}$ & $\begin{array}{l}264 \\
177(67 \cdot 2 \%) \\
87\end{array}$ \\
\hline
\end{tabular}

The amounts of metals which are likely to be available to Scrobicularia from ingested sediment are almost certainly very low compared with the values in Table 2. However, the trends for both total and extractable concentrations suggest that, with the exception of lead, availability will fall markedly in a downstream direction.

The mean, maximum and minimum concentrations of all ten metals for whole soft parts, digestive gland, surface sediment and Fucus vesiculosus are summarized in Table 3.

\section{DISCUSSION}

By considering the more abundant metals individually, an attempt will be made to describe the relationships between concentrations in Scrobicularia and its environment. 
Table 3. Summary of concentrations of heavy metals in Tamar Estuary from 1974 surveys

Numbers of stations $(\mathrm{km})$ in Fig. 1 are shown in parentheses

Concentrations (ppm dry weight)

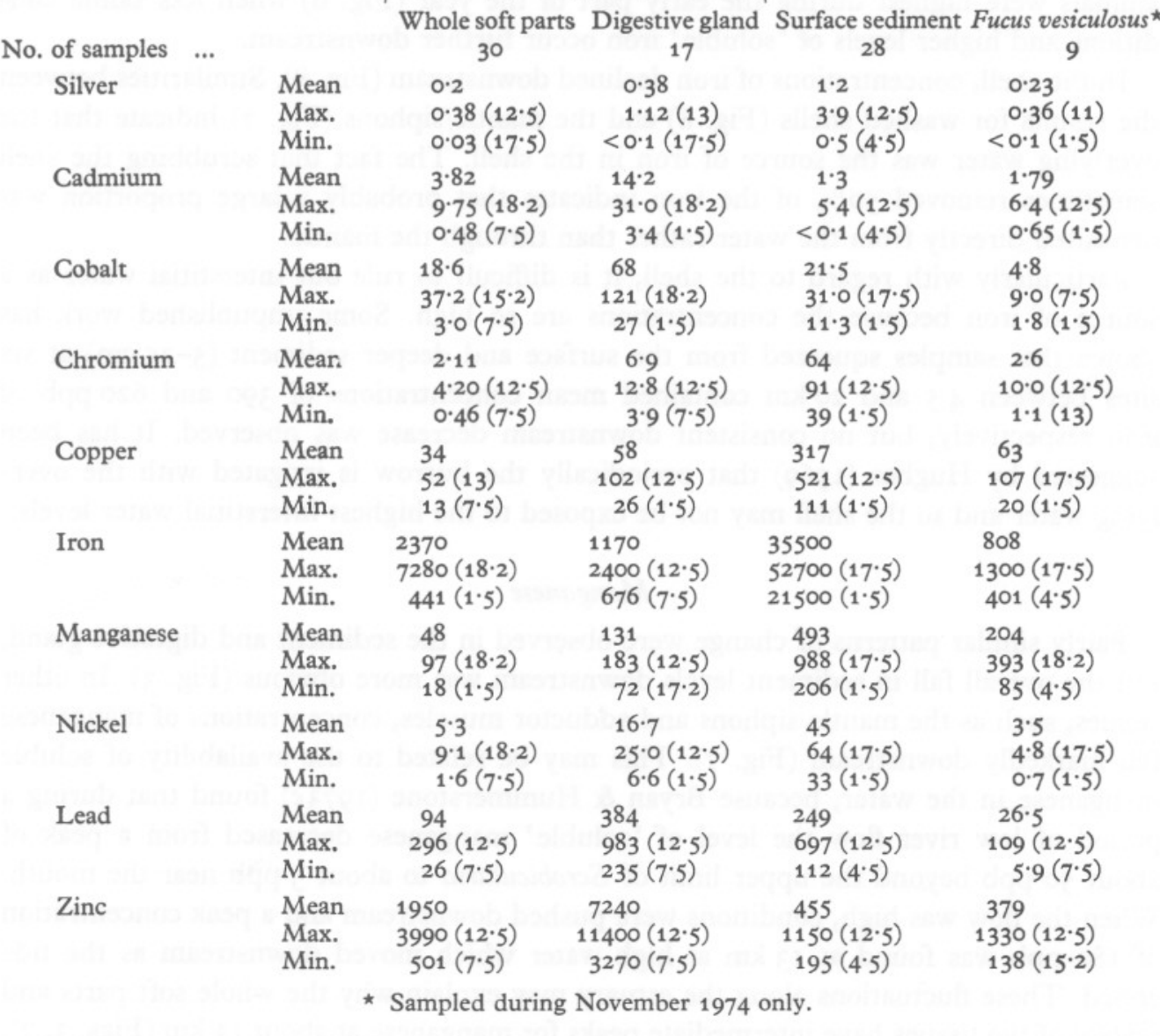

\section{Iron}

In the sediments, concentrations of iron decreased gradually downstream and this appeared to be mirrored by the digestive gland, which is the main organ for the digestion and absorption of ingested material (Fig. 3, Table 2). On the other hand, Bryan \& Hummerstone $(1973 \mathrm{c})$ showed that in the water the concentration of 'soluble' iron fell markedly from around $80 \mathrm{ppb}$ in fresh water entering the estuary to less than $1 \mathrm{ppb}$ near the mouth. This appears to be related to the downstream decrease observed in the remaining tissues, such as the mantle/siphons and adductor muscles, which are in close contact with the water (Fig. 7). It can be concluded from these observations that analyses of the digestive gland indicate changes in the availability of iron from ingested sediment, whereas analyses of the remaining tissues, especially the mantle/siphons, reflect the influence of 'soluble' iron in the water. 
In the whole soft parts, concentrations fell from 7000-8000 ppm upstream to 500$600 \mathrm{ppm}$ downstream, coinciding with an increase in the contribution of the digestive gland to the total iron content from $3 \%$ upstream to $20 \%$ downstream. This certainly suggests that soluble or colloidal iron in the water was the main source for the high levels in animals from upstream stations. So also does the observation that levels in animals were highest during the early part of the year (Fig. 6) when less saline conditions and higher levels of 'soluble' iron occur further downstream.

In the shell, concentrations of iron declined downstream (Fig. 8). Similarities between the results for washed shells (Fig. 8) and the mantle/siphons (Fig. 7) indicate that the overlying water was the source of iron in the shell. The fact that scrubbing the shell sometimes removed $50 \%$ of the iron indicates that probably a large proportion was deposited directly from the water rather than through the mantle.

Particularly with regard to the shell, it is difficult to rule out interstitial water as a source of iron because the concentrations are so high. Some unpublished work has shown that samples squeezed from the surface and deeper sediment $(5-25 \mathrm{~cm})$ at six sites between 4.5 and $20 \mathrm{~km}$ contained mean concentrations of 390 and $620 \mathrm{ppb}$ of iron respectively, but no consistent downstream decrease was observed. It has been suggested by Hughes (1969) that periodically the burrow is irrigated with the overlying water and so the shell may not be exposed to the highest interstitial water levels.

\section{Manganese}

Fairly similar patterns of change were observed in the sediment and digestive gland, but the overall fall in sediment levels downstream was more obvious (Fig. 3). In other tissues, such as the mantle/siphons and adductor muscles, concentrations of manganese fell markedly downstream (Fig. 7). This may be related to the availability of soluble manganese in the water, because Bryan \& Hummerstone (1973c) found that during a period of low river flow the level of 'soluble' manganese decreased from a peak of about $50 \mathrm{ppb}$ beyond the upper limit of Scrobicularia to about $5 \mathrm{ppb}$ near the mouth. When the flow was high, conditions were pushed downstream and a peak concentration of $180 \mathrm{ppb}$ was found at $13 \mathrm{~km}$ at high water which moved downstream as the tide ebbed. These fluctuations along the estuary may explain why the whole soft parts and several of the tissues have intermediate peaks for manganese at about $13 \mathrm{~km}$ (Figs. 3, 7). The pattern for Fucus vesiculosus in November 1974, following a period of high river flow, also indicates the presence of an intermediate peak for 'soluble' manganese in the estuary (Fig. 3).

The clear seasonal changes shown in Fig. 6 cannot simply be explained in terms of changes in the availability of manganese. For example, the highest levels in the water would be expected in the winter during periods of high river flow, whereas those in the animal occur in June and July. Frazier (1975) concluded that concentrations of manganese in the tissues of the oyster Crassostrea virginica were correlated with shell deposition because, during the period of shell growth, the levels in the soft parts increased appreciably. He also concluded that turnover of manganese in the tissues was rapid since the amount deposited in the shell, which contained about $500 \mathrm{ppm}$, was far in excess of the body burden. Much less manganese was found in the shell of Scrobicularia (Fig. 8) and 
it was impossible to explain the decline in the concentration of the soft parts in Fig. 6 by its incorporation into the shell. Well-developed gonads were seen in animals in July and it is possible that the peak concentrations in June and July (Fig. 6) were caused by an increase in metabolic rate leading to the production and maturation of the gonads. However, there was no evidence that manganese is directly involved in gonad development.

The constancy of manganese concentrations in shells from the same station and shells of different size (Table 1, Fig. 8) suggests that most of the metal is incorporated as the shell is laid down by the mantle. This is supported by the observation that concentrations were similar in living shells and those from animals which appeared to have died in situ (Fig. 8C). Between 17.5 and $1.5 \mathrm{~km}$, the concentration in the scrubbed shells (Fig. 8B) decreased from 44 to $5 \mathrm{ppm}$ and in the mantle/siphons from 50 to $5 \mathrm{ppm}$. The mantle/ siphons results were subject to seasonal variation (Fig. 6), but their influence on the shell is presumably smoothed by the fact that most shell growth occurs in the warmer months, and a $4 \mathrm{~cm}$ shell is laid down over a period of perhaps 6 years. These results suggest that the concentration in the shell is directly related to that of the mantle which, in turn, may be directly related to that in solution. This would agree with the work of Gordon, Carr \& Larson (1970), which established a direct relationship between manganese in barnacle shells and that in the water. The possiblity that there is an effect of salinity on the manganese level of the shell produced by changing the manganese/ calcium ratio cannot be ruled out, but the soluble concentration of manganese appears to be the most important factor. Changes in the manganese content of mollusc shells in areas of different salinity have been considered as a possible method of establishing palaeosalinities using fossils (Rucker \& Valentine, 1961). Results from the present work preclude the use of such a method to compare different areas, since the availability of manganese varies between different estuaries. We have found that concentrations of manganese in shells from other estuaries decrease downstream and so differences in concentration in shells from a small area might indirectly indicate salinity variations.

It has been shown that 'soluble' manganese in the water influences concentrations in the shell and soft tissues such as the mantle/siphons and adductor muscles. The main exception is the digestive gland which more nearly reflects changes in the sediments. In July 1974, the contribution of the digestive gland to the total manganese content of the soft parts increased from $51 \%$ at $18.2 \mathrm{~km}$ to $80 \%$ at $4.5 \mathrm{~km}$. It is concluded that at downstream stations, the animal probably obtains most of its manganese from the sediments, but that upstream the intake of 'soluble' manganese becomes very significant.

\section{Copper}

Changes in the concentration of copper in the tissues along the estuary are not as obvious as those in the sediments or Fucus vesiculosus (Figs. 3, 7). Bryan \& Hummerstone $(1971,1973 c)$ showed that copper levels in the burrowing polychaete Nereis diversicolor decreased markedly downstream, and also that in the water the level of 'soluble' copper decreased from about $5 \mathrm{ppb}$ above the upper limit of Scrobicularia to $1 \mathrm{ppb}$ near the mouth of the estuary. Why levels of copper in Scrobicularia should 
change less than those in other organisms has not been explained. There may be subtle changes in the sediment which influence availability, or possibly competition from other metals or organic material at upstream stations which tends to inhibit the uptake of copper. Some unpublished experiments using ${ }^{64} \mathrm{Cu}$ showed that copper was absorbed from solution about three times more readily by the gills and mantle/siphons than by the digestive gland and other tissues. They also showed that the rate of uptake of copper was decreased by increasing the level of zinc. We have already seen that 'soluble' concentrations of iron and manganese were much higher upstream and so the possibilities of competition between metals are very real. It is difficult to judge the relative importance of copper absorption from solution and from ingested particles, but the fact that the digestive gland accounts for about $30 \%$ only of the copper content of the soft parts suggests that uptake from solution is not negligible.

As in the soft parts, concentrations in the shell did not change markedly along the estuary. Probably some copper was incorporated via the mantle, but the readiness with which it was removed from the washed shells by scrubbing suggests that much of it is probably absorbed directly from solution.

\section{Zinc}

Unlike iron, manganese and copper, the concentration of zinc in the soft parts is appreciably higher than in the sediment (Fig. 3). Most of the zinc lies in the digestive gland. In July 1974, the contribution of this organ to the zinc content of the soft parts was about $90 \%$ at upstream stations and $70 \%$ downstream. Concentrations in the digestive gland and whole soft parts appear to be related to those in the sediment, although the tissue levels are rather higher at upstream stations than might be expected (Fig. 3). There are several possible reasons for this, namely, (i) the results in Table 2 suggest that the amount of extractable zinc in the sediment increases upstream rather more rapidly than the total concentration; (ii) the possibility that the metal is taken up more readily at lower salinities cannot be ruled out; and (iii) the concentration in the animal increases with increasing size, and we have some evidence that the slope of this line increases when, as at upstream stations, more zinc is available. Thus the concentration in the animal may increase more rapidly than the apparent increase in the availability of zinc in the sediment.

The high proportion of zinc in the digestive gland almost certainly comes from ingested particles. Some unpublished experiments showed that absorption of zinc labelled with ${ }^{65} \mathrm{Zn}$ from solution is very slow. After 41 days of uptake from $60 \%$ sea water containing about $16 \mathrm{ppb}$ of zinc, the exchange of the isotope with the stable element was only $0.2 \%$ in the digestive gland, about $7 \%$ in the mantle/siphons, $4 \%$ in the gills/labial palps and $14 \%$ in the shell. Bryan \& Hummerstone $(1973 c)$ found that, in the summer when the river flow was low, the concentration of 'soluble' zinc in the estuary decreased from about $15 \mathrm{ppb}$ above the upper limit of Scrobicularia to $1 \mathrm{ppb}$ near the mouth. However, analyses of Fucus vesiculosus at different seasons during 1969-70 gave patterns of the type shown in Fig. 3, which indicates that the average availability of zinc in the water falls sharply above the $13 \mathrm{~km}$ station. Of Scrobicularia tissues which are exposed to the water, such as the mantle/siphons and shell, only the latter shows a pattern 
resembling that for the weed (Figs. 7, 8). Possibly, the mantle/siphons absorb most of their zinc during the summer, whereas the shell and seaweed results reflect conditions during the year as a whole. The soft tissues are not necessarily exposed to the same conditions as seaweed, because the lowest salinities during the tidal cycle can be avoided by closing the shell (cf. p. 92).

The similarity between the shell and seaweed results certainly suggest that most of the zinc associated with the shell comes directly from the overlying water, and not via the mantle which shows a different pattern (Figs. 3, 7, 8). Why the concentration of zinc in the shell increases so markedly with increasing size is uncertain (Fig. 8A). This change is not related to a similar relationship for the whole soft parts (Fig. $5 \mathrm{~A}$ ) because this depends mainly on changes in the digestive gland and not in the mantle/siphons. We favour the idea that zinc is irreversibly being accumulated by the shell directly from the water. This is supported by analyses of different parts of the shell (Table 1) which show that concentrations of zinc decrease from the oldest to the youngest part.

It is concluded that, with the exception of its influence on the shell, 'soluble' zinc is a relatively minor source for Scrobicularia compared with that associated with ingested sediment.

\section{Other metals}

Silver. The values shown in Fig. 4 are approaching the limit of detection in tissues (about $0.1 \mathrm{ppm}$ ) but, in both 1974 surveys, a similar pattern with two peaks was observed. This suggests that there were two additional inputs to the estuary, one at $12.5 \mathrm{~km}$ from the old South Tamar Mine and another of unknown origin at $4.5 \mathrm{~km}$. It is difficult to judge whether silver is absorbed mainly from particles or from solution. Of the other metals, it seems to behave like copper in that concentrations of both decrease with increasing size (Fig. 5) and, on average, the digestive gland accounts for about $39 \%$ of the silver and $31 \%$ of the copper in the body.

Cadmium. Results for cadmium are very similar to those for zinc (Figs. 3-5). Most of the metal is probably absorbed from ingested particles because, in July 1974, the contribution of the digestive gland to the total in the soft parts increased from $82 \%$ at $4.5 \mathrm{~km}$ to $98 \%$ at $18.2 \mathrm{~km}$.

Cobalt. The results in Figs. 4 and 5 are not unlike those for zinc and cadmium, although the influence of mining at $12.5 \mathrm{~km}$ is absent. With the exception of a value of $72 \%$ at $7.5 \mathrm{~km}$, the contribution of the digestive gland to the cobalt content of the soft parts in July 1974 was between 90 and $95 \%$. This evidence points to uptake from particulates being especially important; Amiard-Triquet \& Amiard (1976) concluded from experiments using ${ }^{60} \mathrm{Co}$ that accumulation by the digestive gland results from feeding, whereas uptake from solution occurs in the external tissues. However, as Fig. 4 shows, concentrations in the animal increase much more markedly in an upstream direction than total concentrations in the sediment, which implies changes in the proportion of available cobalt in the sediment. There is no evidence from the seaweed analyses (Fig. 4) of an upstream increase in the availability of 'soluble' cobalt and at present we have no explanation of these results.

Chromium. The results in Fig. 4 show that apart from peaks corresponding to some 
input from the old South Tamar Mine at $12.5 \mathrm{~km}$, there is a general tendency for concentrations to increase upstream. Although the concentration in the digestive gland is almost an order of magnitude lower than that of the sediment, this organ contains about $76 \%$ of the total in the body suggesting that absorption from particles is important.

Nickel. The results in Fig. 4 are not unlike those for cobalt, with the concentrations in the whole soft parts and digestive gland increasing more rapidly upstream than those of the sediments. The availability of cobalt to Scrobicularia must exceed that of nickel considerably, since cobalt concentrations in the sediment are lower but cobalt in the tissues is much higher. Uptake from particles is probably less important for nickel than cobalt, although in July 1974 the digestive gland contained about $77 \%$ of the nickel in the soft parts.

Lead. The results in Fig. 3 show a close similarity between the patterns for the animal and the total concentration in the sediment, with a marked peak showing the influence of the South Tamar lead mine at $12.5 \mathrm{~km}$. In fact, the results show a similar pattern to those of Fucus, although the low level in the weed, and the occurrence of about $82 \%$ of the body lead in the digestive gland, suggests that the sediments are the main source for the animal.

\section{Summary and conclusions}

Usually more than $75 \%$ of the cadmium, cobalt, chromium, nickel, lead and zinc in the soft parts of Scrobicularia lies in the digestive gland. Since the animal feeds on sediment, and this organ is an important site for digestion and absorption, its high metal content suggests that the sediment is the most important source for these six metals. Certainly in the case of zinc, some unpublished experiments showed that it was absorbed very slowly from solution. The function of the digestive gland as a site for metal storage seems to be particularly important in Scrobicularia because the concentrations of the six metals already considered increase as the animal grows, showing that the rate of intake exceeds that of loss.

Evidence of the significant absorption of metals from solution, in addition to sediments, was found for iron and manganese where, apparently as a result of the absorption of 'soluble' forms by tissues other than the digestive gland, the proportion of iron $(20-3 \%)$ and manganese $(80-51 \%)$ in the digestive gland was reduced at upstream stations. The fact that only $30-40 \%$ of the total silver and copper was found in the digestive gland implies that uptake from solution might be relatively important but, unlike iron and manganese, there was no clear evidence for this. Metals in solution appear to be the main source for those associated with the shell. An appreciable amount of uptake probably takes place directly from solution and, out of copper, iron, manganese and zinc, only manganese appeared to be incorporated largely during shell deposition by the mantle.

It is concluded that Scrobicularia may be a good indicator of the availability of most heavy metals in sediments. This is particularly true for metals which are abundant in the digestive gland, since the partitioning of metals between this organ and the remaining tissues seems to give an indication of the relative importance of uptake from the sediments and of uptake from solution in the water. 
We are very grateful to U.N.E.S.C.O. for a grant to one of us (H.U.) and to the then Director Dr J. E. Smith for providing facilities. Thanks are also due to Mr L. G. Hummerstone for his assistance throughout this work and to the South West Water Authority for providing flow data for the River Tamar. Part of the research was financed by the Department of the Environment under Contract DGR 480/51.

\section{REFERENCES}

Akberali, H. B., Marriott, K. R. M. \& Trueman, E. R. (1977). Calcium utilisation during anaerobiosis induced by osmotic shock in a bivalve mollusc. Nature, London, 266, 852-853.

Amiard-Triquet, C. \& Amiard, J.-C., 1976. L'organotropisme du ${ }^{60} \mathrm{Co}$ chez Scrobicularia plana et Carcinus maenas en fonction du vecteur de contamination. Oikos, 27, 122-126.

Boyden, C. R., 1974. Trace element content and body size in molluscs. Nature, London, 251, 311-314.

British Standards Institution, 1961. Methods of Testing Soils for Civil Engineering Purposes. B.S. 1377.140 pp. British Standards Institution.

Bryan, G. W. \& Hummerstone, L. G., 1971. Adaptation of the polychaete Nereis diversicolor to estuarine sediments containing high concentrations of heavy metals. I. General observations and adaptation to copper. Fournal of the Marine Biological Association of the United Kingdom, 51, 845-863.

Bryan, G. W. \& Hummerstone, L. G., 1973 a. Adaptation of the polychaete Nereis diversicolor to estuarine sediments containing high concentrations of zinc and cadmium. fournal of the Marine Biological Association of the United Kingdom, 53, 839-857.

Bryan, G. W. \& Hummerstone, L. G., 1973 $b$. Adaptation of the polychaete Nereis diversicolor to manganese in estuarine sediments. Fournal of the Marine Biological Association of the United Kingdom, 53, 859-872.

BRYAN, G. W. \& HuMmerstone, L. G., 1973c. Brown seaweed as an indicator of heavy metals in estuaries in South-West England. Fournal of the Marine Biological Association of the United Kingdom, 53, 705-720.

Bryan, G. W. \& Hummerstone, L. G., 1977. Indicators of heavy-metal contamination in the Looe Estuary (Cornwall) with particular regard to silver and lead. Fournal of the Marine Biological Association of the United Kingdom, 57, 75-92.

Chester, R. \& Hughes, M. J., 1967. A chemical technique for the separation of ferro-manganese minerals, carbonate minerals and adsorbed trace elements from pelagic sediments. Chemical Geology, 2, 249-262.

FrazIER, J. M., 1975. The dynamics of metals in the American oyster, Crassostrea virginica. I. Seasonal effects. Chesapeake Science, 16, 162-171.

Freeman, R. F. H. \& RigleR, F. H., 1957. The response of Scrobicularia plana (da Costa) to osmotic pressure changes. Fournal of the Marine Biological Association of the United Kingdom, 36, 553-567.

Gordon, C. M., CARR, R. A. \& LaRson, R. E., 1970. The influence of environmental factors on the sodium and manganese content of barnacle shells. Limnology and Oceanography, 15, 461466.

GreEN, J., 1957. Growth of Scrobicularia plana in the Gwendraeth Estuary. Fournal of the Marine Biological Association of the United Kingdom, 36, 41-47.

Hughes, R. N., 1969. A study of feeding in Scrobicularia plana. fournal of the Marine Biological Association of the United Kingdom, 49, 805-823.

Hughes, R. N., 1970. Population dynamics of the bivalve Scrobicularia plana (da Costa) on an intertidal mudflat in North Wales. Fournal of Animal Ecology, 39, 333-356.

LANGMYR, F. J. \& PAUS, P. E., 1968. The analysis of inorganic siliceous materials by atomic absorption spectrophotometry and the hydrofluoric acid decomposition technique. I. The analysis of silicate rocks. Analytica chimica acta, 43, 397-408.

Percival, E., 1929. A report on the fauna of the estuaries of the River Tamar and the River Lynher. Fournal of the Marine Biological Association of the United Kingdom, 16, 721-742.

RUCKER, J. R. \& VAlENTINE, J. W., 1961. Salinity response of trace element concentration in Crassostrea virginica. Nature, London, 190, 1099-1100. 
Spooner, G. M. \& Moore, H. B., 1940. The ecology of the Tamar estuary. VI. An account of the macrofauna of the intertidal muds. Fournal of the Marine Biological Association of the United Kingdom, 24, 283-330.

Theede, H., Ponat, A., Hiroki, K. \& Schlieper, C., 1969. Studies on the resistance of marine bottom invertebrates to oxygen-deficiency and hydrogen sulphide. Marine Biology, 2, 325337. 